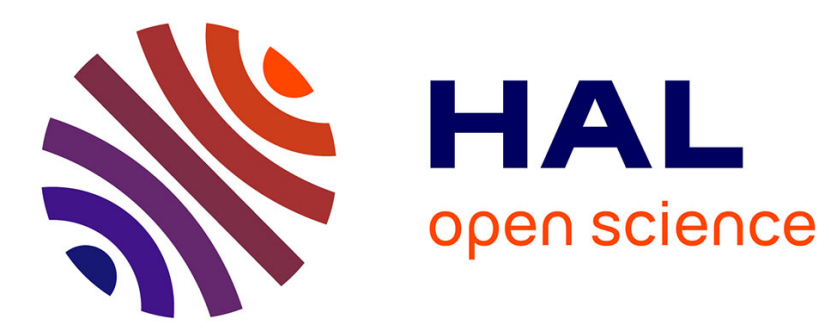

\title{
A novel growth process of calcium carbonate crystals in silk fibroin hydrogel system
}

Yufei Ma, Qingling Feng, Xavier Bourrat

\section{To cite this version:}

Yufei Ma, Qingling Feng, Xavier Bourrat. A novel growth process of calcium carbonate crystals in silk fibroin hydrogel system. Materials Science and Engineering: C, 2013, 33, pp.2413-2420. 10.1016/j.msec.2013.02.006 . insu-00804520

\section{HAL Id: insu-00804520 https://hal-insu.archives-ouvertes.fr/insu-00804520}

Submitted on 27 Mar 2013

HAL is a multi-disciplinary open access archive for the deposit and dissemination of scientific research documents, whether they are published or not. The documents may come from teaching and research institutions in France or abroad, or from public or private research centers.
L'archive ouverte pluridisciplinaire HAL, est destinée au dépôt et à la diffusion de documents scientifiques de niveau recherche, publiés ou non, émanant des établissements d'enseignement et de recherche français ou étrangers, des laboratoires publics ou privés. 


\title{
A Novel Growth Process of Calcium Carbonate Crystals in Silk Fibroin Hydrogel System
}

\author{
Yufei Ma ${ }^{a}$, Qingling Feng ${ }^{b, *}$ and Xavier Bourrat ${ }^{c}$ \\ ${ }^{a}$ State key laboratory of new ceramics and fine processing, Department of Materials Science and \\ Engineering, Tsinghua University, Beijing 100084, China \\ ${ }^{\mathrm{b}}$ Laboratory of Advanced Materials, Department of Materials Science and Engineering, Tsinghua \\ University, Beijing 100084, China \\ ${ }^{\mathrm{c}}$ CNRS, ISTO, 1A rue de la Ferollerie, F-45071 Orleans cedex2, France
}

*Corresponding author at: Department of Materials Science and Engineering, Tsinghua University, Haidian District, Beijing 100084, China.

Fax: 86-10-62771160; Tel: 86-10-62782770.

E-mail: biomater@mail.tsinghua.edu.cn (Qingling Feng). 


\section{ABSTRACT}

We report an interesting finding of calcium carbonate $\left(\mathrm{CaCO}_{3}\right)$ crystal growth in the silk fibroin (SF) hydrogel with different concentrations by a simple ion diffusion method. The experimental results indicate that the $\mathrm{CaCO}_{3}$ crystals obtained from silk fibroin gels with low and high concentrations are all calcites with unusual morphologies. Time-dependent growth study was carried out to investigate the crystallization process. It is believed that silk fibroin hydrogel plays an important role in the process of crystallization. The possible formation mechanism of $\mathrm{CaCO}_{3}$ crystals is proposed. This study provides a better explanation of the influence of silk fibroin concentration and its structure on $\mathrm{CaCO}_{3}$ crystals growth.

Keywords: Biomimetic; Crystal growth; Polymers; silk fibroin hydrogel; Biomineralization

\section{Introduction}

Calcium carbonate is an important mineral due to its significance as a biomineral and its various industrial applications [1-3]. As a kind of considerable biomineral, it receives much attention due to the wide existence in nacre of mollusk shells, crustacean exoskeletons, and eggshells [3, 4]. Thereinto, one of the most striking biomaterials, nacre has inspired researchers to investigate the formation mechanisms for decades [5-7]. It is well-known that the formation of nacre layers is closely related to the templating effect of organic matrix during $\mathrm{CaCO}_{3}$ crystallization. Nacre organic matrix is comprised of three major components: acidic proteins, $\beta$-chitin and silk-fibroin-like protein [8, 9]. Among the organic matrices involved in nacre, acidic proteins are considered to play a pivotal role during the formation of aragonite crystals in the nacre sheets. In recent years, most of the studies have 
concentrated on the role of acidic proteins in nacre [10-12]. Zhang et al. [10] identified a novel acidic protein from the nacreous layer of Pinctada fucata that could control $\mathrm{CaCO}_{3}$ crystal growth and induce the needle-like aragonite crystals. Gong et al. [11] determined a nacre protein from pearl oyster and this protein might initiate crystal nucleation and permit further calcium deposit formation with irregular morphology. $\beta$-chitin acted as a structural scaffold and its effect often required the cooperation of other organic matrix, such as acidic proteins [13]. Silk-fibroin-like protein, rich in glycine and alanine, is a kind of insoluble protein with a secondary structure of antiparallel $\beta$-sheet. It has been found that silk fibroin (Bombyx mori) is much more similar to silk-fibroin-like protein in nacre in amino acid sequence and secondary structure [14] compared to the conventional synthesized acidic polymers [15-19]. Hence, silk fibroin has been used as an additive in the solution to investigate its effect on $\mathrm{CaCO}_{3}$ crystal growth in in-vitro study. Wang et al. [20] found $\mathrm{CaCO}_{3}$ formation steps greatly depended on the presence of silk fibroin in mineralization process. A cryo-transmission electron microscopy (CTEM) study of the structure of the Atrina shell nacreous organic matrix without dehydration suggested that [9], at least prior to mineralization, the silk-fibroin-like protein existed as a hydrated gel phase. Nudelman et al. [21] also identified a hydrated gel-like protein filling the space between two interlamellar sheets prior to mineral formation. These results showed that mineral formation did not occur in aqueous solution, but in a hydrated gel-like medium. However, the exact role of this hydrogel in nacre growth is still so far limited.

In our research, we used a silk fibroin hydrogel system, which is beneficial to mimic the real mineralization system of nacre. The motivation for this research is to explore how silk fibroin gel mediates the crystal growth of calcium carbonate. In addition, by studying the crystallization process in silk fibroin gel, the probable mechanism of $\mathrm{CaCO}_{3}$ crystal growth is proposed. Generally speaking, this 
study provides clues to understand $\mathrm{CaCO}_{3}$ biomineralization process as it occurs in nacre and suggests a pathway for the biomimetic fabrication of functional materials.

\section{Experimental Section}

\subsection{Materials}

Calcium chloride (AR) and sodium carbonate (AR) were bought from Chemical Agents Co. Ltd., Beijing, China. Bombyx mori silkworm silk was purchased from Yi Xian Raw Silk Factory in China. All chemicals were used without further purification. Deionized water was used throughout the experimental process.

2.2 Preparation of silk fibroin hydrogel

Degumming and dissolving process of Bombyx mori silk followed the established procedures [22]. About $6 \%(\mathrm{w} / \mathrm{w})$ of aqueous regenerated silk fibroin was collected at room temperature and stored at $4{ }^{\circ} \mathrm{C}$. Silk fibroin solutions with lower concentrations were prepared by diluting the $6 \%$ solution with water. To obtain higher concentration solutions, the $6 \%$ silk fibroin solutions were dialyzed against $10 \%(\mathrm{w} / \mathrm{v})$ PEG $(10,000 \mathrm{~g} / \mathrm{mol})$ solution for at least $12 \mathrm{~h}$ at room temperature [23]. Finally, silk fibroin solutions with different concentrations (w/w, 5\%,10\%, 15\% and 25\%) were prepared. Silk fibroin solutions with these four concentrations containing $\mathrm{CaCl}_{2}(20 \mathrm{mM})$ were prepared, then the hydrogels formed at $60{ }^{\circ} \mathrm{C}$ after $20 \mathrm{~h}$. Silk fibroin gel was cut into small cubes (volume: $\sim 1 \mathrm{~cm}^{3}$ ) as shown in figure 1.

2.3 Crystallization of $\mathrm{CaCO}_{3}$ crystals in silk fibroin hydrogel

In-vitro crystallization experiments in the gels with the different silk fibroin concentrations were carried out. The gel cubes were immersed in $\mathrm{Na}_{2} \mathrm{CO}_{3}$ solution $(20 \mathrm{mM}, 200 \mathrm{ml})$ and the mineralization 
process lasted for $12 \mathrm{~h}$ at room temperature. In the control group, $\mathrm{CaCO}_{3}$ crystals grown in the same condition without silk fibroin gels were collected by silicon substrates. For the time-dependent growth study, $\mathrm{CaCO}_{3}$ crystallization experiment was carried out within $10 \%$ silk fibroin gel and stopped at the designed time from $5 \mathrm{~min}$ to $12 \mathrm{~h}$. When the mineralization process completed, the final products were lyophilized for characterization.

\subsection{Characterization}

The cross-sections of the gel cubes with four silk fibroin concentrations were chosen to analyze calcium distribution qualitatively by using electron probe microanalyzer (JXA-8230, JEOL). Crystal morphology and crystallization process were imaged by LEO-1530 (LEO Company) scanning electron microscope (SEM), fitted with a field-emission source operating at an accelerating voltage of $15 \mathrm{kV}$. Phase analyses were performed by a Nicolet 6700 (ThermoFisher SCIENTIFIC) Fourier transform infrared (FTIR) spectrometer using the KBr pellets method and a D8 ADVANCE (BRUKER Company) X-ray diffractometer with $\mathrm{Cu} \mathrm{K \alpha}$ radiation $(40 \mathrm{kV}, 40 \mathrm{~mA})$. XRD patterns of silk fibroin/ $/ \mathrm{CaCO}_{3}$ hybrids were collected at a $2 \theta$ range of $10-80^{\circ}$. Additionally, a RM 2000 laser microscopic Raman spectrometer (Renishaw Company) with the Raman shifts ranging from 100 to $1200 \mathrm{~cm}^{-1}$ was also used to confirm the polymorph. An argon ion laser at a wavelength of $514.5 \mathrm{~nm}$ was used.

\section{Results and Discussion}

3.1 Effect of silk fibroin hydrogel with different concentrations on calcium carbonate crystal growth

Calcium distribution of the four gels with different concentrations was investigated first and the typical surface scanning images are shown in figure 2 . Analysis area is $100 \mu \mathrm{m} \times 100 \mu \mathrm{m}$. Warm color represents high level of calcium element content and cool color is reversed. Test results show that the 
detected calcium is homogeneously distributed in these samples. Additionally, calcium content obviously decreased as silk fibroin concentration increased. High silk fibroin content leads to the low solvent content in equal volume, accompanying with the same calcium ion concentration, which results in the low calcium content.

In-vitro crystallization experiments in silk fibroin gels with varying concentrations and control group without silk fibroin gels were carried out at room temperature $\left(\sim 25^{\circ} \mathrm{C}\right)$. Morphologies of the pure silk fibroin gel and resulting $\mathrm{CaCO}_{3}$ crystals were characterized in figure 3a-f. A uniform network with porous structure is revealed in pure silk fibroin gel (figure 3a). Figure $3 \mathrm{~b}$ shows $\mathrm{CaCO}_{3}$ crystals obtained from the control group without silk fibroin gels. The typical calcite crystals with the exposed (104) crystalline faces are observed. In the experiment groups, the morphology of $\mathrm{CaCO}_{3}$ crystals is homogeneous in each silk fibroin concentration (figure 3c-f), and it is well controlled in silk fibroin hydrogel. To further investigate the details of morphology, $\mathrm{CaCO}_{3}$ crystals from the four experiment groups are magnified, as shown in figure $4 \mathrm{a}-\mathrm{d}$. With the increase of silk fibroin concentration, $\mathrm{CaCO}_{3}$ crystals morphology transforms from regular rhombohedral appearance (figure 4a), step-like morphology (figure 4b-c) to spherical aggregate (figure 4d). The typical (104) facets are clearly observed on the crystal surface in figure 4a-d, suggesting that these crystals are all calcites. Meanwhile, the obtained crystal sizes differ in the four kinds of gels. From 5\% SF gel to $25 \%$ SF gel, the corresponding crystal size is $\sim 24 \mu \mathrm{m}, \sim 21 \mu \mathrm{m}, \sim 14 \mu \mathrm{m}$ and $\sim 16 \mu \mathrm{m}$ respectively. According to the difference in calcium content, the larger crystal size in low silk fibroin concentration gel can be attributed to the higher calcium content. Additionally, it could be a result of fast growth rate of calcite in the case of lower concentration of silk fibroin. Figure 5 shows XRD patterns and FTIR spectra of the pure silk fibroin gel and silk fibroin/ $\mathrm{CaCO}_{3}$ hybrids from the four crystallization experiments. The 
typical XRD patterns in figure 5a clearly exhibits that no sharp peak is involved in the pure silk fibroin gel, leaving only a broad peak at about $20^{\circ}$. The four silk fibroin/ $\mathrm{CaCO}_{3}$ hybrids have a similar pattern. The diffraction peaks at $2 \theta$ of $29.4^{\circ}, 35.9^{\circ}$ and $39.5^{\circ}$ correspond to (104), (110) and (113) crystallographic planes of calcite, respectively [24]. As can be seen in figure 5b, the peak in the ranges of $1620-1625 \mathrm{~cm}^{-1}$ (amide I) and around $1516 \mathrm{~cm}^{-1}$ (amide II) are attributable to $\beta$-sheet structure of silk fibroin [25]. The peaks at 876 and $712 \mathrm{~cm}^{-1}$ associated with $v 2\left(\mathrm{CO}_{3}\right.$ out-of-plane deformation) mode and v4 (OCO bending in-plane deformation) mode vibrations are distinctive features of calcite [26]. Thus, it can be concluded that the prepared $\mathrm{CaCO}_{3}$ products are calcite crystals and silk fibroin gel has no effect on $\mathrm{CaCO}_{3}$ polymorph. Chen et al. [27] reported that silk fibroin as a soluble additive could induce rice-grain-shaped aragonite crystals. As we know, secondary structure of silk fibroin can be changed from random coil to $\beta$-sheet during the gel formation. Consequently, we presume that the difference in silk fibroin conformation is responsible for the polymorph diversity.

\subsection{Calcium carbonate crystallization process in silk fibroin hydrogel}

To learn the detail of $\mathrm{CaCO}_{3}$ crystallization process in silk fibroin gel system, time-dependent growth study was carried out. Observations using SEM show in detail the crystallization process of calcium carbonate (figure 6). At the early stage, the typical rhombohedral crystals with uniform crystal size of $\sim 3 \mu \mathrm{m}$ are observed (figure 6a). In succession, the initial crystals grow bigger and the well-facetted calcite crystals are obtained (figure 6b). As reaction time goes on, the single calcite crystal reveals multilayered morphology but the well-defined (104) facet is still observed. The calcite crystal size reached to $\sim 9 \mu \mathrm{m}$ (figure 6c). Figure 6d-e show $\mathrm{CaCO}_{3}$ crystal growth at 6 and $8 \mathrm{~h}$ respectively. Interestingly, the sheet-like crystals with smooth surface appear, suggesting the dissolution process is involved in this process [20]. Micro-Raman spectra demonstrated these sheet-like 
crystals are calcite (inset in figure 6d). It has three vibrational bands at $282 \mathrm{~cm}^{-1}, 713 \mathrm{~cm}^{-1}$ and 1087 $\mathrm{cm}^{-1}$, which can be attributed to [libration/rotation, $L$ ] lattice vibrations of the calcite crystals, $v 4$ in-plane $\mathrm{C}-\mathrm{O}$ bending mode vibration and $v 1$ symmetric $\mathrm{C}-\mathrm{O}$ stretching mode vibration respectively [28]. The size of this dissolved calcite reduced continually as the reaction time increased. Estroff $e t$ al. [29] reported that the dissolution was observed on the gel-grown calcite crystals. As a result of cross-linked macromolecules, the biological calcite increased solubility as compared to synthetic calcite. Similarly, calcite with the dissolved morphology was also prepared with polyacrylamide hydrogel [30]. Figure $6 f$ shows the growth state of $\mathrm{CaCO}_{3}$ in silk fibroin gel for $12 \mathrm{~h}$. Irregular rhombohedral calcite with steps recrystallized under the control of silk fibroin gel and the final crystal size was $\sim 21 \mu \mathrm{m}$. Hence, calcite crystals growth in silk fibroin gel passed through the dissolution to conduct mass transport and then recrystallization process. All observations indicated that calcite formed at initial stage and no phase transition was existed in crystal growth process. Silk fibroin hydrogel could regulate the morphology but not polymorph.

In combination with background information and our experimental results, the proposed growth mechanism of calcium carbonate crystals in silk fibroin gels with high and low concentration is illuminated (figure 7). Generally, the formation of $\mathrm{CaCO}_{3}$ crystals in silk fibroin hydrogel contains four steps: (1) silk fibroin gelation, (2) preliminary crystallization, (3) dissolving, and (4) recrystallization. Initially, the structure of silk fibroin in the solution with calcium chloride changed from random coil to $\beta$-sheet, with some inter-chain physical cross-links to form the gel network. Calcium distributed uniformly in both high and low concentration gels, and calcium content in high concentration gel was lower than that in low concentration gel. When carbonate ions diffused into the gel and contacted with calcium ions, calcium ions served as nucleation centers and then preliminary crystallization happened 
to form calcite crystals. Next, the grown calcite dissolved to conduct mass transport, along with the precursor formation. $\beta$-sheet of silk fibroin could cause the partial orientation of the protein chains [27]. The formed precursor tended to absorb on the highly oriented crystalline region of silk fibroin because of the nucleation-dependent aggregation of $\beta$-sheets [31]. Finally, recrystallization took place on the region of $\beta$-sheets due to the high localized concentration of sequestered $\mathrm{Ca}^{2+}$. Growth of $\mathrm{CaCO}_{3}$ crystals was highly restrained in the gel network. This restrictive effect of macromolecule network in high concentration gel was much stronger than that in low concentration gel. Thus, the spherical calcite aggregates formed in high concentration gel (figure 7a), while the single irregular calcites appeared in low concentration gel (figure $7 \mathrm{~b}$ ).

\section{Conclusion}

In this paper, we documented a sample system only containing silk fibroin hydrogel for a better mimicking of calcium carbonate biomineralization process in nacre. SEM and FTIR spectra confirmed the concentration of silk fibroin gel had influence on calcium carbonate morphology rather than polymorph. $\mathrm{CaCO}_{3}$ crystals obtained from the low and high concentration gels were all calcites with different morphologies. On the basis of the study on $\mathrm{CaCO}_{3}$ crystallization process in silk fibroin gel, a potential growth mechanism of calcium carbonate was proposed. Preliminary crystallization, dissolving and recrystallization were involved in crystal growth process. The difference in restrictive effect of macromolecule network led to the obviously different $\mathrm{CaCO}_{3}$ morphologies in varying concentration gels. Although detailed crystallographic data of $\mathrm{CaCO}_{3}$ were not available from the present study, the results demonstrated significant aspects of calcium carbonate crystals grown in gel, which could further provide clues for a deeper understanding of $\mathrm{CaCO}_{3}$ biomineralization process as it occurs in nature and 
suggest a pathway for the biomimetic fabrication of functional materials.

\section{Acknowledgments}

The authors are grateful for the financial support from National Natural Science Foundation of China (51072090, 51061130554) and Doctor Subject Foundation of the Ministry of Education of China (20100002110074).

\section{References}

[1] M. Suzuki, H. Nagasawa, T. Kogure, Cryst. Growth Des. 6 (2006) 2004-2006.

[2] N. Gehrke, H. Colfen, N. Pinna, M. Antonietti, N. Nassif, Cryst. Growth Des. 5 (2005) 1317-1319.

[3] J.M. Ouyang, Prog. Chem. 17 (2005) 749-756.

[4] X.A. Zhang, J.F. Wang, W.J. Wu, C.L. Liu, J. Inorg. Mater. 21 (2006) 257-266.

[5] S. Weiner, L. Addadi, J. Mater. Chem. 7 (1997) 689-702.

[6] L. Addadi, D. Joester, F. Nudelman, S. Weiner, Chem-Eur. J. 12 (2006) 981-987.

[7] J.H.E. Cartwright, A.G. Checa, J. R. Soc. Interface 4 (2007) 491-504.

[8] G. Falini, S. Albeck, S. Weiner, L. Addadi, Science 271 (1996) 67-69.

[9] Y. Levi-Kalisman, G. Falini, L. Addadi, S. Weiner, J. Struct. Biol. 135 (2001) 8-17.

[10] C. Zhang, S. Li, Z. Ma, L. Xie, R. Zhang, Mar. Biotechnol. 8 (2006) 624-633.

[11] N. Gong, Z. Ma, Q. Li, Q. Li, Z. Yan, L. Xie, R. Zhang, Mar. Biotechnol. 10 (2008) 457-465.

[12] Y.F. Ma, Y.H. Gao, Q.L. Feng, J. Cryst. Growth 312 (2010) 3165-3170.

[13] G. Falini, S. Fermani, A. Ripamonti, J. Inorg. Biochem. 91 (2002) 475-480.

[14] S. Sudo, T. Fujikawa, T. Nagakura, T. Ohkubo, K. Sakaguchi, M. Tanaka, K. Nakashima, T. Takahashi, Nature 387 (1997) 563-564.

[15] L. He, R. Xue, R. Song, J. Solid State Chem. 182 (2009) 1082-1087.

[16] N. Wada, S. Suda, K. Kanamura, T. Umegaki, J. Colloid Interf. Sci. 279 (2004) 167-174.

[17] S.R. Payne, M. Heppenstall-Butler, M.F. Butler, Cryst. Growth Des. 7 (2007) 1262-1276.

[18] A. Kotachi, T. Miura, H. Imai, Cryst. Growth Des. 6 (2006) 1636-1641.

[19] A. Sugawara, A. Oichi, H. Suzuki, Y. Shigesato, T. Kogure, T. Kato, J. Polym. Sci. Pol. Chem. 44 (2006) 5153-5160.

[20] T. Wang, R. Che, W. Li, R. Mi, Z. Shao, Cryst. Growth Des. 11 (2011) 2164-2171.

[21] F. Nudelman, E. Shimoni, E. Klein, M. Rousseau, X. Bourrat, E. Lopez, L. Addadi, S. Weiner, J. Struct. Biol. 162 (2008) 290-300.

[22] Y.H. Yang, Z.Z. Shao, X. Chen, P. Zhou, Biomacromolecules 5 (2004) 773-779.

[23] U.J. Kim, J.Y. Park, C.M. Li, H.J. Jin, R. Valluzzi, D.L. Kaplan, Biomacromolecules 5 (2004) 
786-792.

[24] R. Fried, Y. Mastai, J. Cryst. Growth 338 (2012) 147-151.

[25] A. Matsumoto, J. Chen, A.L. Collette, U.-J. Kim, G.H. Altman, P. Cebe, D.L. Kaplan, J. Phys. Chem. B 110 (2006) 21630-21638.

[26] F.A. Andersen, L. Brecevic, Acta Chem. Scand. 45 (1991) 1018-1024.

[27] C. Cheng, Z. Shao, F. Vollrath, Adv. Funct. Mater. 18 (2008) 2172-2179.

[28] S.R. Stock, A. Veis, X. Xiao, J.D. Almer, J.R. Dorvee, J. Struct. Biol. 180 (2012) 280-289.

[29] L.A. Estroff, L. Addadi, S. Weiner, A.D. Hamilton, Org. Biomol. Chem. 2 (2004) 137-141.

[30] O. Grassmann, P. Lobmann, Chem-Eur. J. 9 (2003) 1310-1316.

[31] G.Y. Li, P. Zhou, Z.Z. Shao, X. Xie, X. Chen, H.H. Wang, L.J. Chunyu, T.Y. Yu, Eur. J. Biochem. 268 (2001) 6600-6606. 


\section{Figure captions}

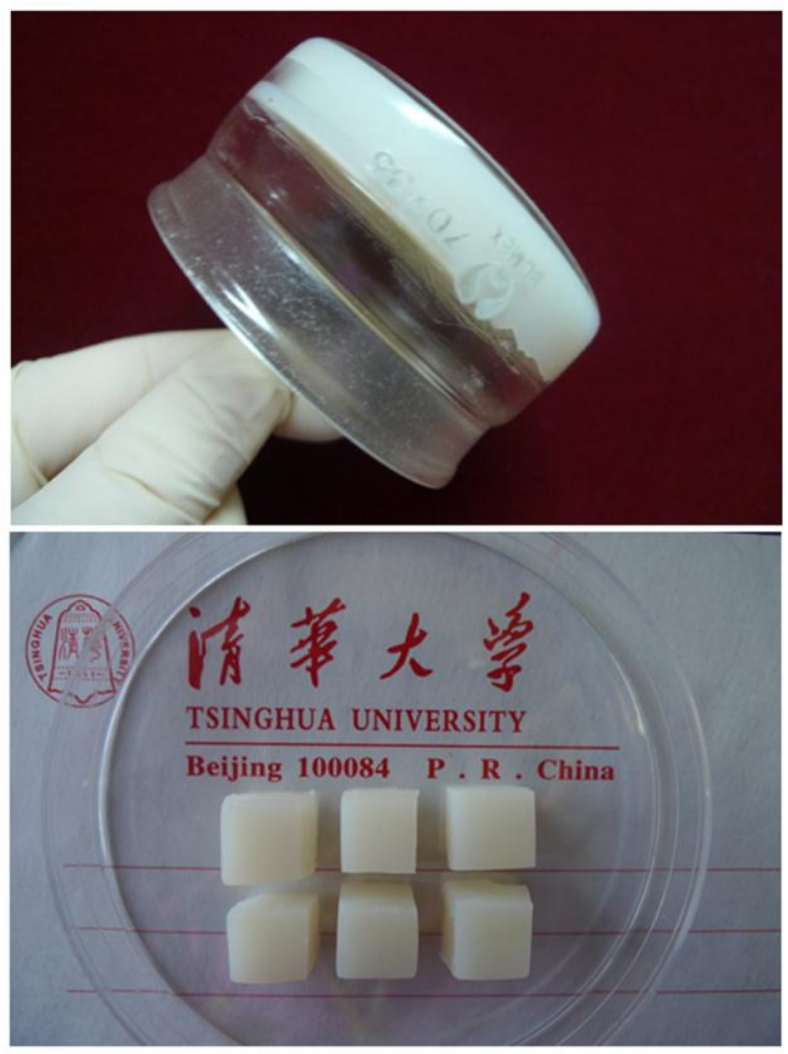

Figure 1. Optical photos of the silk fibroin hydrogel and small gel cubes.

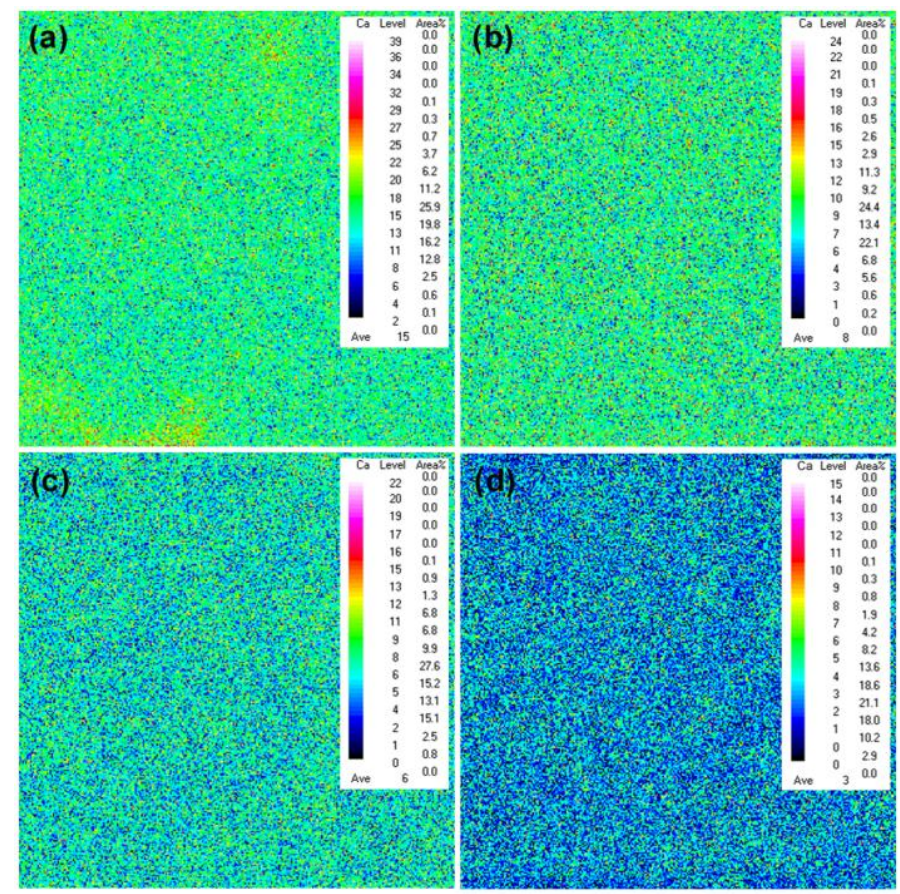

Figure 2. Calcium distribution features in silk fibroin hydrogels with different silk fibroin concentrations (wt. \%): (a) $5 \%$, (b) $10 \%$, (c) $15 \%$, and (d) $25 \%$. 

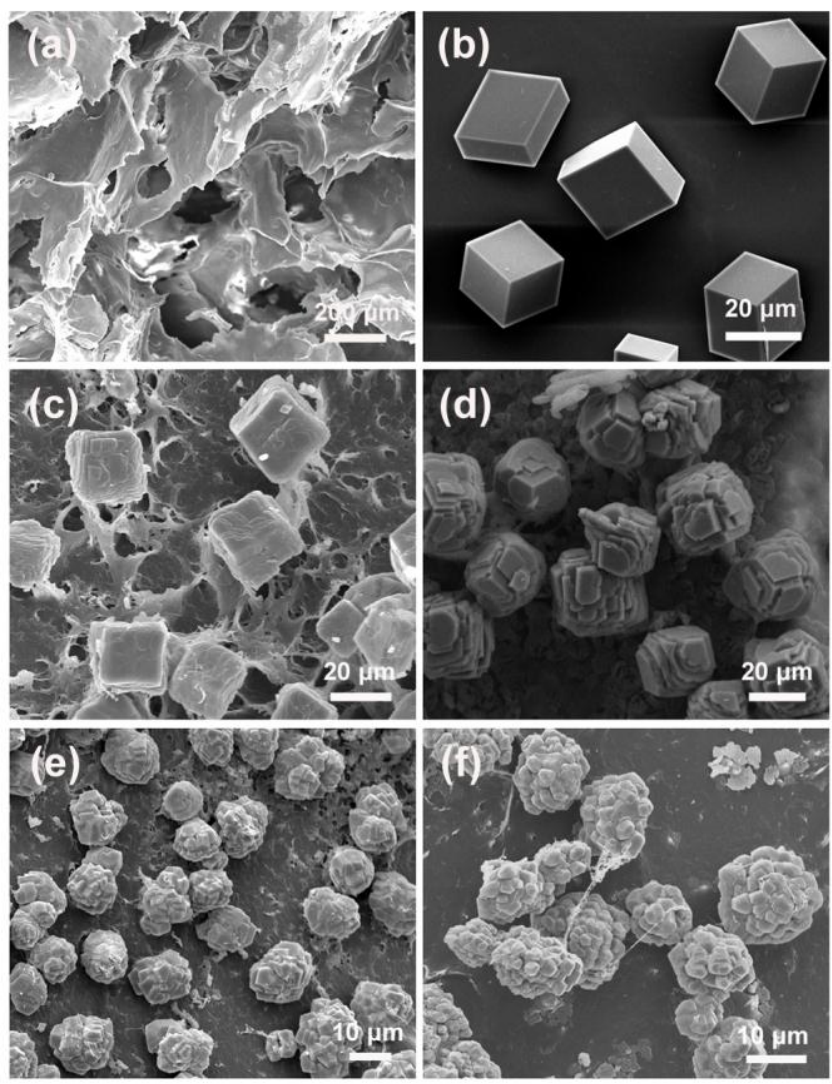

Figure 3. SEM images of the pure silk fibroin gel (a), $\mathrm{CaCO}_{3}$ crystals grown without silk fibroin gels

(b) and $\mathrm{CaCO}_{3}$ crystals grown in the gels with varying silk fibroin concentrations (wt. \%): (c) $5 \%$, (d)

$10 \%$, (e) $15 \%$, and (f) $25 \%$.
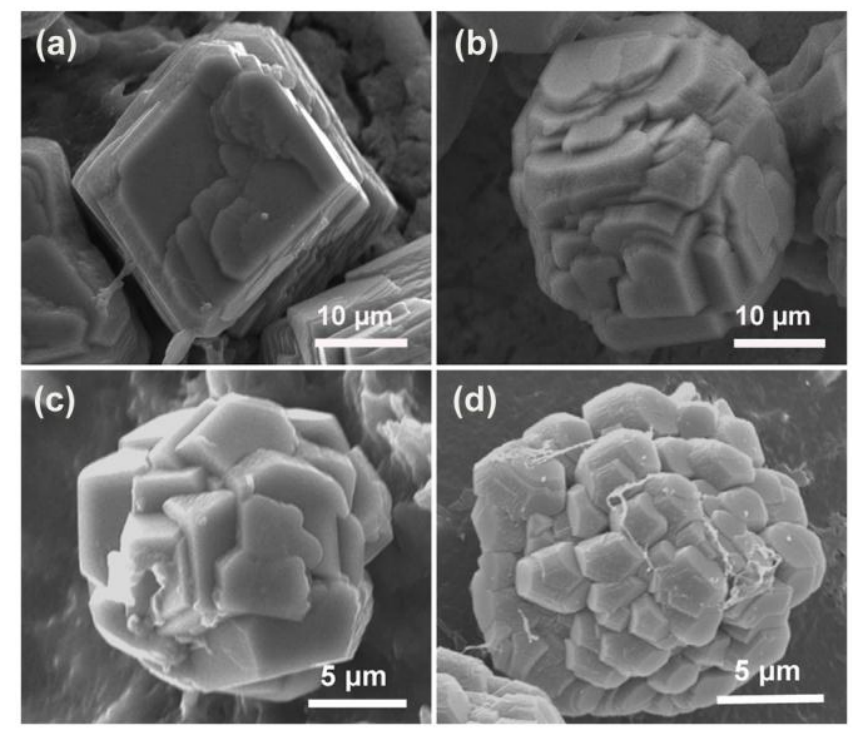

Figure 4. SEM images of magnified $\mathrm{CaCO}_{3}$ crystals grown in silk fibroin hydrogel with varying silk

fibroin concentrations (wt. \%): (a) 5\%, (b) 10\%, (c) 15\%, and (d) $25 \%$. 
(a)

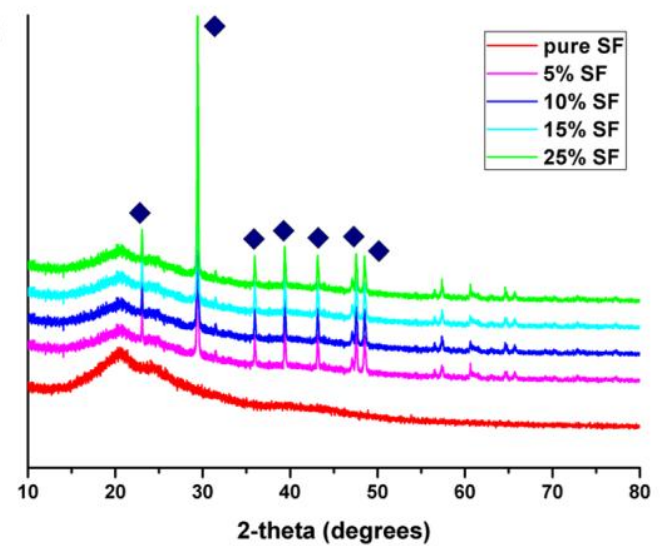

(b)

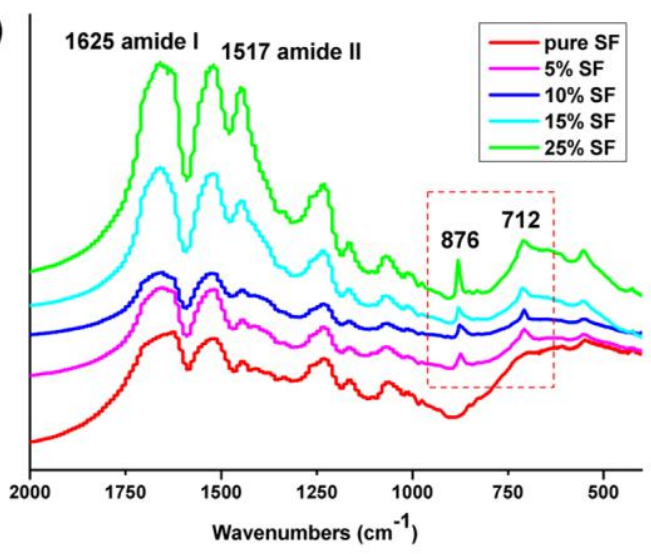

Figure 5. XRD patterns (a) and FTIR spectra (b) of the pure silk fibroin gel and silk fibroin/ $\mathrm{CaCO}_{3}$ hybrids. 

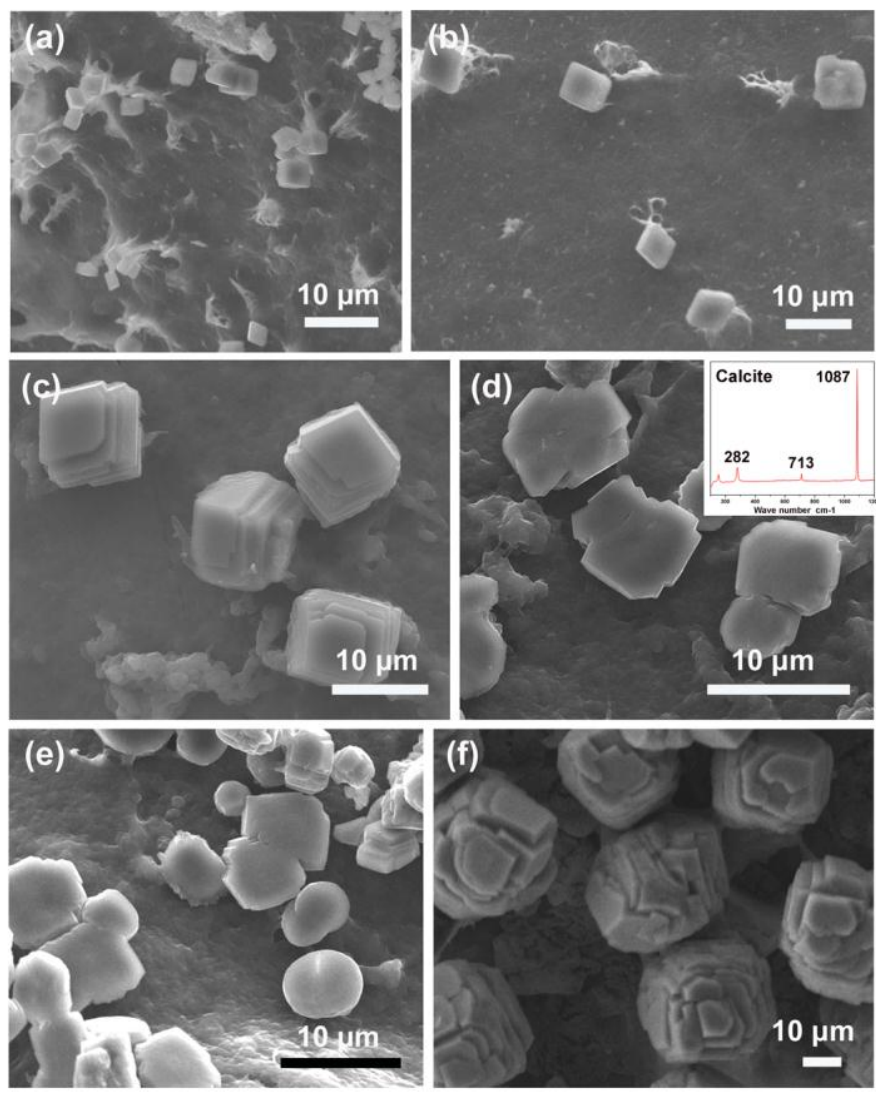

Figure 6. SEM images of crystallization process of $\mathrm{CaCO}_{3}$ crystals in $10 \%$ silk fibroin hydrogel at different interval: (a) $5 \mathrm{~min}$, (b) $10 \mathrm{~min}$, (c) $2 \mathrm{~h}$, (d) $6 \mathrm{~h}$, (e) $8 \mathrm{~h}$, and (f) $12 \mathrm{~h}$. Inset shows polymorph of the sheet-like crystal by micro-Raman spectra.

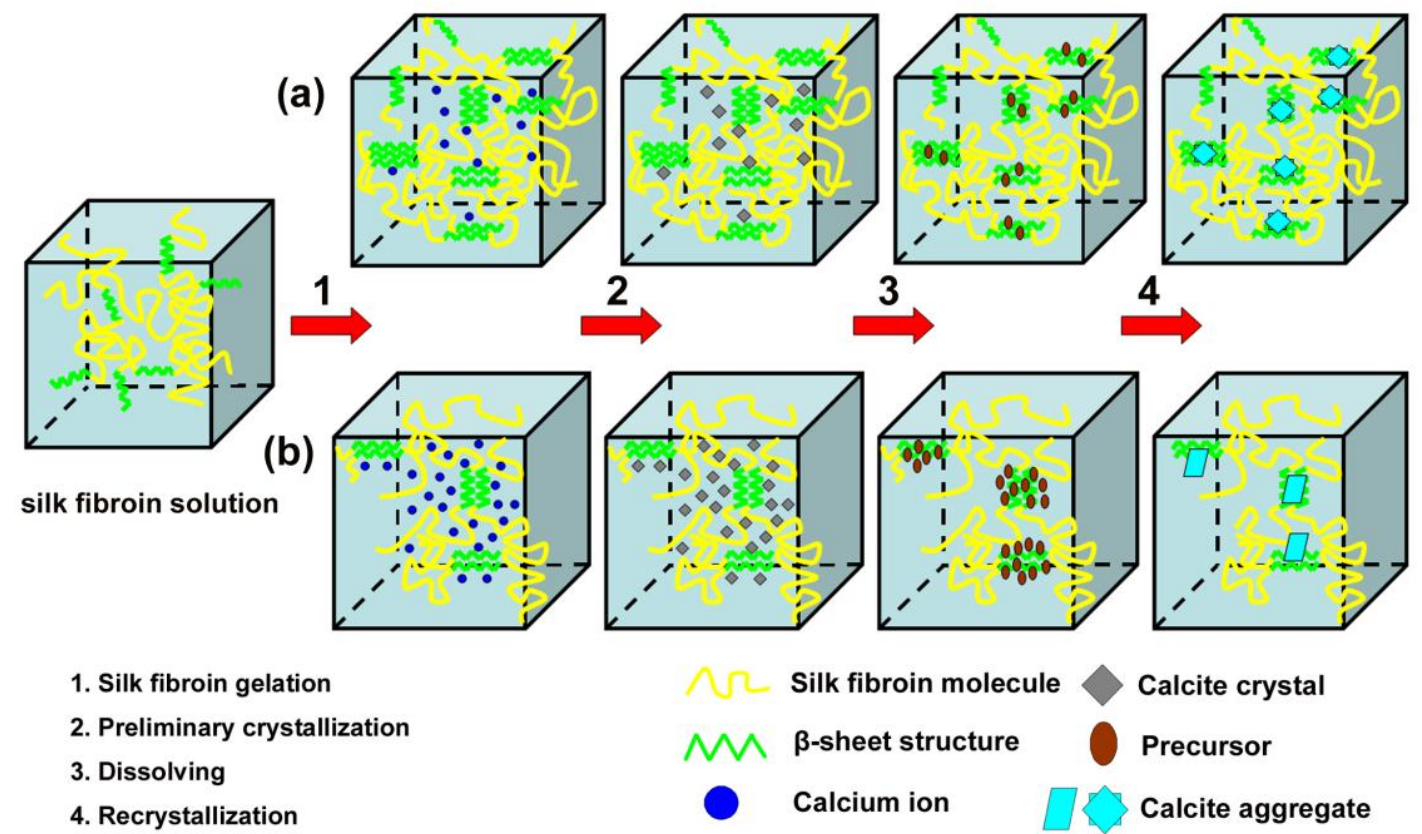


Figure 7. Schematic illustration of $\mathrm{CaCO}_{3}$ crystals growth process in (a) high concentration and (b) low concentration silk fibroin hydrogels. 